\title{
PHẪU THUÂT GHÉP TIM ĐỒNG VỊ TRÍ KỸ THUẠTT CHỦ - CHỦ TẠI BỆNH VIỆN TRUNG ƯƠNG HUẾ
}

Bùi Đức Phú và cộng sụ *

\section{Tóm tắt}

Thành công ghép tim trên người được thực hiện bởi Barnard vào năm 1967. Cho đến nay, ghép tim được xem là phương thức điều trị triệt để cho bệnh nhân suy tim giai đoạn cuối. Gần đây, kỹ thuật ghép tim đồng vị trí theo kiểu hai tĩnh mạch chủ nhằm giữ lại phần mô tâm nhĩ của tim người cho đã được áp dụng trong lâm sàng như là một phương pháp thay thế cho ghép tim kinh điên theo kỹ thuật hai nhĩ . Chúng tôi trình bày trường hợp ghép tim đầu tiên theo kỹ thuật hai tĩnh mạch chủ tại Bệnh viện Trung ương Huế. Những thuận lợi chính của phương pháp này là cải thiện dòng máu phụt ngược qua van ba lá, ít gây rối loạn nhịp nhĩ, và cải thiện chức năng co bóp của tâm nhĩ sau mổ.

\section{Abstract}

The first success of human heart transplantation was performed by Barnard in 1967. To date, heart transplantation is consided as a current treatment for patients with end-stage heart failure. In recent years, bicaval orthotopic cardiac transplantation leaving the right atrium intact has been introduced into clinical practice as an alternative to the standard method of biatrial technique. We present our first heart transplantation performed by bicaval technique in Hue Central Hospital. Possible additional advantages include a decreased incidence of tricuspid regurgitation, fewer atrial arrhythmias, and improved atrial contractile function.

\section{I. ĐẠTT VẤN ĐỀ}

Ghép tim đồng vị trí theo kỹ thuật kinh điển kiểu hai tâm nhĩ được mô tả bởi Lower va Shumway 1960 [9] và Barnard thực hiện trên người năm 1967, kể từ đó kỹ thuật này được áp dụng phổ biến tại nhiều trung tâm trên thế giới. Tuy nhiên, việc thực hiện miệng nối giữa hai tâm nhĩ của người cho và người nhận đã làm thay đổi kích thước giải phẫu cũng như hình thái chức năng tâm nhĩ sau ghép. Trên siêu âm tim, người ta khảo sát thường thấy dòng máu phụt ngược qua van hai lá và van ba lá sau ghép. Để tránh các biến đổi huyết động sau mổ này, kỹ thuật ghép tim hai tĩnh mạch chủ đã được Siever và cộng sự áp dụng năm 1991 [8] nhằm nâng cao chất lượng cuộc sống của người bệnh sau ghép. Tại Bệnh viên Trung ương Huế, chúng tôi đã thực hiện ca ghép tim đầu tiên theo

\footnotetext{
* Bệnh viện Trung uoong Huế
}

kỹ thuật này, bằng cách cắt bỏ toàn phần tâm nhĩ bệnh lý ở người nhận, và bảo tồn tâm nhĩ của người cho và thực hiện hai miệng nối tĩnh mạch chủ theo kiểu khâu nối tận - tận. Áp dụng kỹ thuật này, chúng tôi ghi nhận những kết quả cải thiện rõ nét về huyết động và chức năng ở bệnh nhân hơn một năm sau ghép tim.

\section{II. ĐỐI TƯợNG VÀ PHƯƠNG PHÁP NGHIÊN CÚU 1.Tuyển chọn bệnh nhân chò̀ ghép tim.}

Tuyển chọn 01 người nhận ghép tim trong số 10 bệnh nhân suy tim giai đoạn cuối và có chỉ định ghép tim được điều trị và chuẩn bị để chờ ghép tim tại Bệnh viện Trung ương Huế theo các tiêu chuẩn như sau

- Bệnh lý suy tim giai đoạn cuối và suy tim vẫn tiến triển nặng đến mất bù mặc dù đã được điều trị tích cực. Các tiêu chuẩn đánh giá suy tim mất bù [6] ở bệnh nhân cần được ghép tim được đưa ra dựa vào:

+Tiêu thụ oxy tối đa $<10 \mathrm{ml} / \mathrm{kg}$

+Phân suất tống máu giảm nặng < $20 \%$

+Điều trị nội khoa và đáp ứng với điều trị này là không đáng kể

+Số lần nằm viện do suy tim mất bù

- Tiêu chuẩn người nhận ghép tim theo Hội ghép tim phổi thế giới [6]

+Bệnh tim giai đoạn cuối được chẩn đoán khẳng định +Thể trạng, sinh lý còn chấp nhận được, tuổi < 55

+Không có rối loạn chức năng thận và gan đáng kể

+Không có bệnh lý nhiễm trùng cấp tính

+Không có nhiễm trùng phổi tái phát

+Tâm lý ổn định

+Không nghiện rượu, thuốc lá hay lạm dụng thuốc

- Không có chống chỉ định có liên quan đến điều trị thuốc ức chế miễn dịch như: không có chống chỉ định do bối cảnh tâm lý và xã hội; không có chống chỉ định đặc hiệu của ghép tim do tăng áp động mạch phổi. Nếu sức cản mạch máu phổi (RVP) trước ghép $>4$ đơn vị Wood thì đánh giá các trác nghiệm hồi phục tăng áp phổi với NO hoặc với prostine. Nếu trắc nghiệm dương tính thì có thể tiến hành ghép tim. Trường hợp này thường chọn tim ghép của người cho có cân nặng lớn hơn cân nặng của người nhận. Nếu trắc nghiệm âm tính thì không thể ghép tim mà chỉ có thể ghép cả khối tim và phổi [1]

\section{Tuyển chon người chết não cho tim.}

Tuyển chọn 01 người cho tim ghép trong số 10 bệnh nhân chết não và có đủ tiêu chuẩn cho tim ghép tại 
Bệnh viện Trung ương Huế theo các tiêu chuẩn như sau

- Có chẩn đoán chết não theo tiểu chuẩn của Bộ Y tế và theo Luật chết não của Quốc hội nước cọng hòa xã hội chủ nghĩa Việt Nam [5].

- Tuổi < 55 (trừ trường hợp đặc biệt)

- Không có bệnh tim từ trước

- Không có các yếu tố nguy cơ mắc bệnh động mạch vành

- Không có bệnh nhiễm trùng cấp

- Không có bệnh lý ác tính hệ thống

- Không có chấn thương tim

- Điện tâm đồ bình thường

- HIV và huyết thanh viêm gan âm tính

Tiêu chuẩn tương hợp giữa người cho và người nhận ghép tim dựa trên các tiêu chí chọn tương hợp của Hội ghép tim phổi thế giới [6] về:

- Tương hợp nhóm ABO

- Tương hợp giữa kích thước và cân nặng

- Phản ứng đọ chéo tế bào lympho âm tính bắt buộc trong trường hợp độ tiền mẫn cảm (Panel Reactive Antibodies) ở người nhận PRA $>20 \%$

- Tình trạng cấp cứu của bệnh nhân chờ ghép

- Thời gian chờ ghép của người nhận

- Tính phù hợp của con người và trang thiết bị của trung tâm ghép

\section{Kỹ thuật mổ ghép tim đồng vị trí kiểu hai tĩnh mach chủ}

- Kỹ thuật mổ lấy tim từ người chết não:

Mở ngực theo đường dọc giữa xương ức. Thám sát quả tim đánh giá sức co bóp, tình trạng đổ đầy các buồng tim, và sự mềm mại của các mạch vành. Sau khi heparin hóa người nhận (liều $3 \mathrm{mg} / \mathrm{kg}$ ) và cặp các tĩnh mạch chủ, động mạch chủ, tiến hành làm lạnh và liệt tim bằng cách bơm dung dịch Plegisol ${ }^{\circledR} 4^{0} \mathrm{C}$ vào gốc động mạch chủ. Tiến hành cắt các các mạch máu lớn ở mức gốc màng tim. Lưu ý, tĩnh mạch chủ trên phải được phẫu tích và cắt ở vị trí cao nhất trong khoang trung thất để có thể thực hiện ghép tim theo kỹ thuật hai tĩnh mạch chủ sau này.

Tim ghép được lấy ra khỏi lồng ngực và được bảo quản bằng cách ngâm trong hộp chứa dung dịch bảo quản, sau đó được gói trong hai lớp nilon vô trùng và được đặt vào trong thùng chứa đá cục vô trùng để vận chuyển về trung tâm ghép .

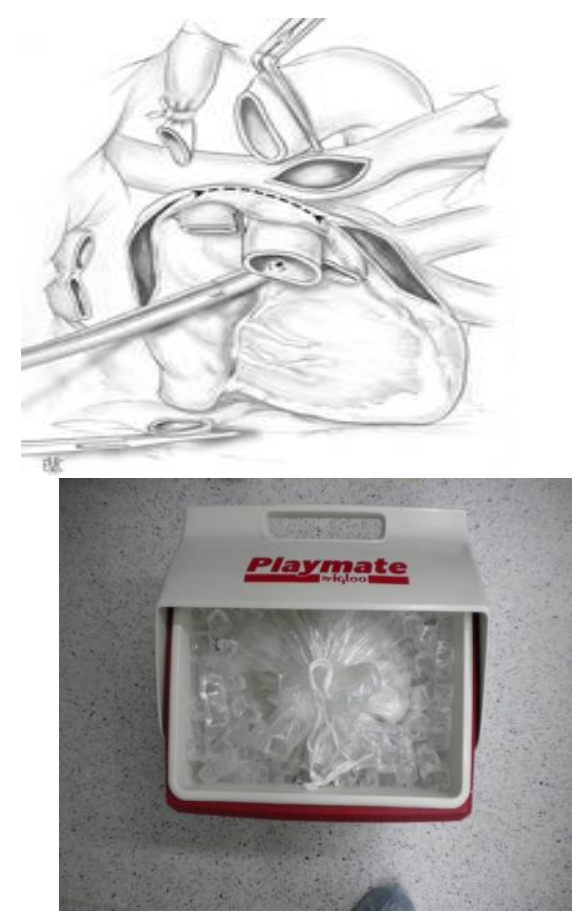

Hình 1: Phẫu thuật lấy và bảo quản tim ghép từ người cho

- Kỹ thuật mổ ghép tim kiểu hai tĩnh mạch chủ trên người nhận

Tiến hành mở ngực thiết lập tuần hoàn ngoài cơ thể vào thời điểm kíp đi lấy tạng trên đường trở về trung tâm ghép. Cần chú ý phải đặt 2 canule TM ở vị trí tỉnh mạch chủ trên và dưới.

Phẫu thuật cắt bỏ tim bệnh lý của người nhận bằng cách cắt các mạch máu lớn, cắt hai tĩnh mạch chủ và tâm nhĩ trái. Đầu tiên khâu miệng nối giữa nhĩ trái của tim ghép với mô tâm nhĩ trái còn lại trên người nhận. Tiểp theo, khâu miệng nối tĩnh mạch chủ dưới rồi đến TMC trên, miệng nối động mạch chủ và cuối cùng là động mạch phổi . Chúng tôi tiến hành kỹ thuật liệt tim máu lạnh mỗi 20 phút sau khi đưa tim ghép vào người nhận.

Sau khi đuổi khí, mở cặp động mạch chủ, tim ghép tiếp tục được hỗ trợ cho đến khi hồi phục chức năng hoàn toàn. Có thể sử dụng thêm các thuốc inotrop ở giai đoạn này nếu cần thiết. Duy trì tần số

tim ghép đạt trên 90 lần/phút. Có thể kích tần số tim bởi isoproterenol hoặc bởi tạo nhịp nhĩ hoặc nhĩ thất (pace maker).

Đánh giá ổn định huyết động sau ghép bằng phương pháp xâm nhập và không xâm nhập (siêu âm tim qua thực quản) và ngưng tuần hoàn ngoài cơ thể, trung hoà Potamin và tiến hành cầm máu dâ̂n lưu đóng ngực như thông lệ. 

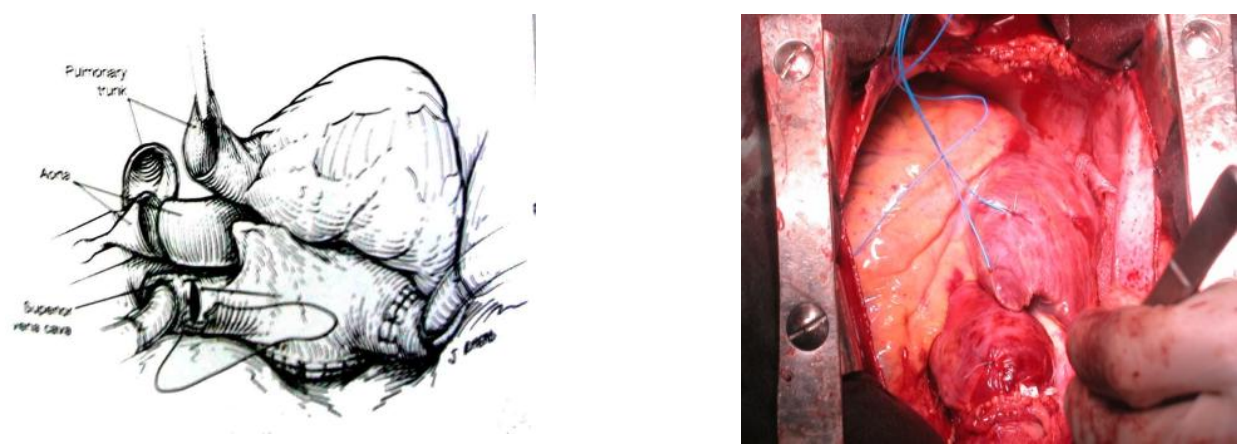

Hình 2: Phẫu thuật ghép tim theo kiểu hai tĩnh mạch chủ

\section{KẾT QUẢ NGHIÊN CÚU}

\section{1.Đặc điểm lâm sàng và cận lâm sàng của ngưòi chết não cho tim}

Bệnh nhân nam, 29 tuổi, Chấn thương sọ não đã được phẫu thuật. Thời gian từ khi đuợc khẳng định chết não (lần 3) đến khi thực hiện phẫu thuật lấy tạng hiến là 12 giờ. Khi tiến hành phẫu thuật lấy tạng, tình trạng huyết áp dao động thấp $50 / 30$ - 70/45 mmHg, bệnh nhân đang được hỗ trợ với inotrop (Adrenaline $0,2 \mathrm{mcg} / \mathrm{kg} / \mathrm{phút})$.

Bảng 1: Các tiêu chuẩn lâm sàng và cận lâm sàng chẩn đoán chết não:

\begin{tabular}{llll}
\hline Tiêu chuẩn LS và CLS & Lần 1 & Lần 2 & Lần 3 \\
\hline Hôn mê sâu (điểm Glasgow) & 3 đ & 3 đđ & 3 đ \\
Đồng tử >4mm & $>4$ & $>4$ & $>4$ \\
Đồng tử mất p/xạ AS & Âm tính & Âm tính & Âm tính \\
Mất p/xạ giác mạc & Âm tính & Âm tính & Âm tính \\
Mất p/xạ mắt búp bê & Âm tính & Âm tính & Âm tính \\
Mất p/xạ kích thích PQ & Âm tính & Âm tính & Âm tính \\
Nghiệm pháp ngừng thở & Dương tính & Dương tính & Dương tính \\
Siêu âm Doppler xuyên sọ & Mất dòng tâm & Mất dòng tâm & Mất dòng tâm \\
Điện não đồ & trương & trương & trương \\
\hline
\end{tabular}

Bảng 2: Kết quả nghiệm pháp ngưng thở

\begin{tabular}{llll}
\hline $\begin{array}{l}\text { PCO2/ Khí máu ĐM } \\
\text { (Nghiệm pháp ngưng thở) }\end{array}$ & Lần 1 & Lần 2 & Lần 3 \\
\hline Trước nghiệm pháp (mmHg) & $33-37$ & $35-38$ & $35-40$ \\
Sau nghiệm pháp (mmHg) & $50-55$ & $50-70$ & $50-70$ \\
Độ thay đổi pCO2(mmHg) & $>12$ & $>10$ & $>15$ \\
\hline
\end{tabular}




\section{Tiêu chuẩn hòa hợp giữa người cho và ngưòi nhận ghép tim}

Bảng 3: Kết quả tương hợp chiều cao và cân nặng

\begin{tabular}{llll}
\hline Thông số & Người nhận & Người cho & Nhận xét \\
\hline Chiều cao & $167 \mathrm{~cm}$ & $1 \mathrm{~m} 65$ & $\begin{array}{l}\text { Tương hợp } \\
\text { chiều cao cân }\end{array}$ \\
Cân nặng & 58 & $65 \mathrm{~kg}$ & $\begin{array}{l}\text { nậng } \\
\text { Chỉ số cơ thể }\end{array}$ \\
ASA & $\mathrm{BMI}=20,79$ & $\mathrm{BMI}=21,03$ & \\
\hline
\end{tabular}

Bảng 4: Một số đặc điểm lâm sàng và cận lâm sàng tim mạch

\begin{tabular}{|c|c|c|}
\hline Thông số & Người nhận & Người cho \\
\hline Nhịp tim & $\begin{array}{l}\text { bloc nhánh trái không } \\
\text { hoàn toàn }\end{array}$ & $\begin{array}{l}\text { Nhịp xoang } \\
60 \text { lần/phút }\end{array}$ \\
\hline $\begin{array}{l}\text { Co bóp thành và vách tâm } \\
\text { thất }\end{array}$ & $\begin{array}{l}\text { Bệnh cơ tim dãn, giảm } \\
\text { động }\end{array}$ & Co bóp tốt \\
\hline Đường kính thất trái & 82mm (dãn lớn) & $48 \mathrm{~mm}$ \\
\hline Phân suất tống máu & 17\% (giảm nhiều) & $62 \%$ \\
\hline Áp lực phổi tâm thu & $\mathrm{PAPS}=50 \mathrm{mmHg}$ & $\mathrm{PAPS}=30 \mathrm{mmHg}$ \\
\hline Các van tim & $\begin{array}{l}\text { Hở } 2 \text { lá } 3,5 / 4, \\
\text { hở } 3 \text { lá } 2 / 4\end{array}$ & Hở 2 lá < 1/4 \\
\hline
\end{tabular}

Bảng 5: Kết quả thông tim và trắc nghiệm gắng sức ở người nhận

\begin{tabular}{ll}
\hline Thông số & Kết quả \\
\hline Áp lực động mạch phổi & SP:71, DP:34, MP:46 \\
Sức cản mạch máu phổi & 3 đơn vị wood \\
Áp lực động mạch chủ & SP:109, DP:69, MP:82 \\
Chỉ số tim & 0,9 lit/phút $/ \mathrm{m}^{2}$ \\
Lưu lượng tim & 1,53 lít/phút \\
Tiêu thụ oxy gắng sức & MVO 2 max $=8 \mathrm{ml} / \mathrm{kg}$ \\
Test dobutamine, prostine & Nhạy cảm ++ \\
\hline
\end{tabular}


Bảng 6: Tương hợp miễn dịch giữa người cho và người nhận

\begin{tabular}{|c|c|c|}
\hline Thông số & Người nhận & Người cho \\
\hline Nhóm máu & Nhóm máu $\mathrm{O} ; \mathrm{Rh}+$ & Nhóm máu O; Rh+ \\
\hline T.sử truyền máu & Không & \\
\hline $\begin{array}{l}\text { Nhóm HLA } \\
\text { (ưu tiên 1) }\end{array}$ & $\begin{array}{l}\text { HLA A: A* } A^{*} 11 \\
\text { HLA-B: B* } \text { B }^{*} 13 \\
\text { HLA-DR: DRB1*15, } \\
\text { DRB1*03 DRB5*, DRB3* }\end{array}$ & $\begin{array}{lll}\text { HLA-A: } & A^{*} & A^{*} 11 \\
\text { HLA-B: } & B^{*} & B^{*} 40 \\
\text { HLA-DR: } & \text { DRB1*12, } \\
\text { DRB1*12 } & \text { DRB3* DRB3* }\end{array}$ \\
\hline KQ đọ chéo & \multicolumn{2}{|c|}{ Âm tính } \\
\hline KT kháng HLA & \multicolumn{2}{|c|}{ Âm tính } \\
\hline
\end{tabular}

Bảng 7: Kết quả vi sinh học

\begin{tabular}{lll}
\hline \multicolumn{1}{c}{ Thông số } & Người nhận & Người cho \\
\hline HBsAg & Âm tính & 0,415 âm tính \\
Anticorps anti- & Âm tính & 72,25 \\
HBs & & \\
Anticorps anti- & Âm tính & dương tính IgM âm tính \\
HBc & & \\
HBeAg & 0,42 dương tính & \\
IgG & $(+) 12,3$ & 0,415 âm tính \\
EBV-IgM & $(-) 7,2$ & Âm tính \\
HIVCOM & 0,401 (-) & Âm tính \\
HCV & Âm tính & 0,227 âm tính \\
Anti-HCV & Âm tính & \\
HCV-DNA & Âm tính & \\
CMV & IgG (+) 250,0 & CMV IgM 0,181 (-) \\
CMV IgM (-) 0,46 & \\
Toxoplasmosis & Toxo IgM (-) 0,34 & \\
Toxo IgG (-) 0.8 & \\
Giang maida & Âm tính & RPR âm tính \\
VDRL, RPR & TPHA âm tính & \\
Rubella & IgM âm tính 0.00 & \\
Tiêm chủng lao & PCR âm tính & \\
& &
\end{tabular}




\section{Kết quả sau phẫu thuật ghép tim}

Bảng 8: Thời gian phẫu thuật ghép tim

\begin{tabular}{lc}
\hline \multicolumn{1}{c}{ Thông số } & Kết quả \\
\hline Thời gian phẫu thuật & 250 phút \\
Thời gian cặp động mạch chủ & 110 phút \\
Thời gian tuần hoàn ngoài cơ thể & 155 phút \\
Thời gian thiếu máu lạnh (không được liệt tim) & 60 phút \\
Thời gian liệt tim trong phẫu thuật ghép & 75 phút \\
Tổng thời gian thiếu máu & 135 phút \\
Thời gian vận chuyển tim ghép & 30 phút \\
\hline
\end{tabular}

Bảng 9: Kết quả huyết động bệnh nhân sau mổ ghép tim 1 tuần

\begin{tabular}{ll}
\hline \multicolumn{1}{c}{ Thông số huyết động } & Kết quả \\
\hline Nhịp tim, tần số tim & 90 lần/phút ( nhịp xoang) \\
Huyết áp động mạch trung bình & $70 \mathrm{mmHg}$ \\
Áp lực nhĩ phải & $7 \mathrm{mmHg}$ \\
Áp lực động mạch phổi trung bình & $12 \mathrm{mmHg}$ \\
Áp lực động mạch phổi bít & $11 \mathrm{mmHg}$ \\
Độ bão hòa oxy máu tĩnh mạch trộn & $72 \%$ \\
Lưu lượng tim & 4,7 lít/phút \\
Chỉ số tim & 2,7 lít/phút/m ${ }^{2}$ \\
Sức cản mạch máu hệ thống & 1100 dyne.sec.cm \\
Sức cản mạch máu phổi & 124 dyne.sec.cm ${ }^{-5}$ \\
\hline
\end{tabular}




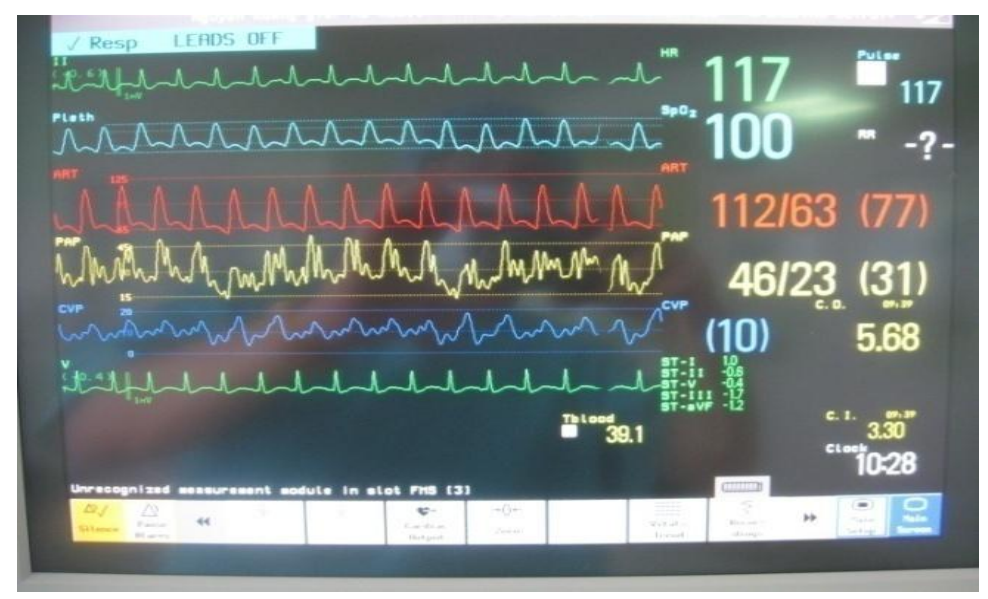

Hình 3: Các thông số huyết động ngay sau mổ

Bảng 10: Kết quả hình thái và chức năng tim ghép trên siêu âm sau mổ 1tuần

\begin{tabular}{lll}
\hline \multicolumn{1}{c}{ Thông số } & \multicolumn{1}{c}{ Bình thường } & \multicolumn{1}{c}{ Bệnh nhân } \\
\hline Chức năng tim & Tốt & Co bóp tốt, đồng dạng \\
ĐK thất trái cuối tâm trương & $<45 \mathrm{~mm}$ & $40 \mathrm{~mm}$ \\
Phân suất tống máu & Tốt & $65 \%$ \\
Buồng tim phải & Tốt & Không dãn \\
Động mạch phổi & Tốt & Không dãn \\
Áp lực động mạch phổi tâm thu & $10-30 \mathrm{mmHg}$ & $25 \mathrm{mmHg}$ \\
Thuốc điều trị tăng áp phổi & $\#$ & Đã ngừng Milrinone \\
\hline
\end{tabular}

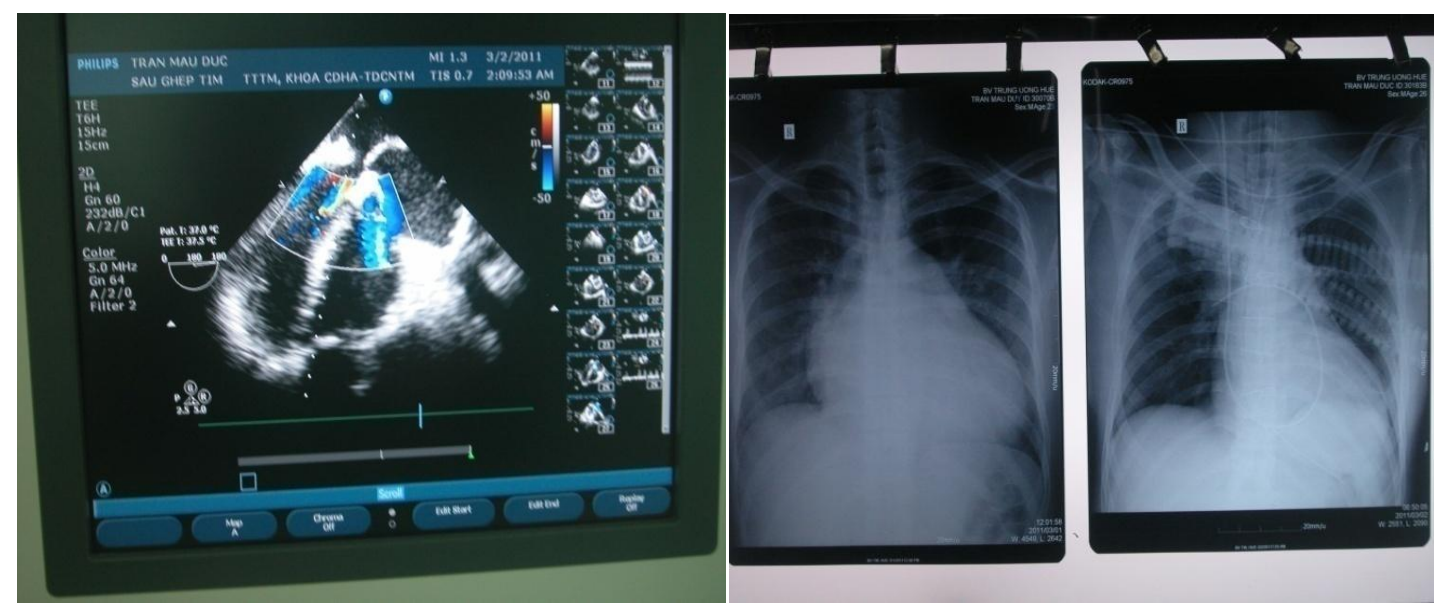

Hình 4: Hình thái và chức năng tim ghép . 
Bảng 11: Kết quả điều trị ức chế miễn dịch sau ghép tim

\begin{tabular}{lll}
\hline Thông số & Giá trị bình thường & Bệnh nhân sau ghép \\
\hline RATG & CD3 \# 50-100/mm & $70 / \mathrm{mm}^{3}$ \\
Cell Cept & $\#$ & Không đáng kể \\
Corticoid & $\#$ & Tăng bạch cầu với liều khởi đầu \\
Neoral & Co \# 200-300 ng $/ \mathrm{ml}$ & Trong giới hạn điều trị \\
\hline
\end{tabular}

Liệu pháp khởi đầu RATG - Cell Cept - Methylprednisolone); Liệu pháp duy trì với bộ ba kinh điển Neoral - Cell Cept - Prednisolone. Kết quả giải phẫu bệnh để chẩn đoán thải ghép cấp không có hình ảnh bất thường tế bào học ở các mẫu sinh thiết cơ tim tại các vùng khác nhau của tâm thất phải. Không có hiện tượng thiếu máu mô, viêm nhiễm, không có hình ảnh tẩm nhuộm tế bào lympho, cũng như hiện tượng tái phân bố mạch máu (thải ghép độ $1 \mathrm{R}$ không có thải ghép mức độ tế bào).

Bảng 12: Kết quả điều trị dự phòng nhiễm trùng

\begin{tabular}{lll}
\hline Tác nhân nhiễm trùng & Dự phòng & Bệnh nhân \\
\hline Nhiễm khuẩn & $\begin{array}{l}\text { Ceftazidime x 14 ngày } \\
\text { Meropenem x 14 ngày }\end{array}$ & $\begin{array}{l}\text { Cấy máu và bệnh phẩm } \\
\text { không mọc }\end{array}$ \\
Nhiễm virus & Valcyte & $\begin{array}{l}\text { huyết thanh IgM }(-) \\
\text { Cáy máu và bệnh phẩm âm } \\
\text { tính }\end{array}$ \\
Nhiễm nấm, ký sinh trùng & $\begin{array}{l}\text { Bactrim } \\
\text { Nystatin, Valcyte }\end{array}$ & $\begin{array}{l}\text { Giảm dần và bình thường } \\
\text { vào ngày } \mathrm{J}_{5}\end{array}$ \\
\hline Biến tượng bạch cầu và & $4-9 \times 10^{3}$ & \\
\hline
\end{tabular}

Bảng 13: Kết quả điều trị sau ghép 14 tháng

\begin{tabular}{ll}
\hline \multicolumn{1}{c}{ Thông số } & \multicolumn{1}{c}{ Bệnh nhân } \\
\hline Chức năng tim & Co bóp tốt, đồng dạng \\
ĐK thất trái cuối tâm trương & $40 \mathrm{~mm}$ \\
Phân suất tống máu & $63 \%$ \\
Buồng tim phải & Không dãn, không hở van 3 lá \\
Động mạch phổi & Không dãn \\
Áp lực động mạch phổi tâm thu & $25 \mathrm{mmHg}$ \\
Thuốc điều trị ức chế miễn dịch & Giảm còn 1/2 liều Neoral \\
Tác dụng phụ liệu pháp ức chế miễn dịch & Prednisolone liều tồi thiêu (5mg) \\
\hline
\end{tabular}


Các biến chứng khác như thải ghép cấp, thải ghép mạn (bệnh mạch vành mạn tính sau ghép), tăng huyết áp, suy thận mạn, hay u ác tính không xảy ra trên bệnh nhân này.

\section{BÀN LUẬN}

Ghép tim về phương diện giải phẫu đòi hỏi 8 miệng nối (4 tĩnh mạch phổi, 2 tĩnh mạch chủ, và 2 động mạch) [4]. Tuy nhiên, kỹ thuật này có nhiều yếu điểm: thời gian liệt tim kéo dài kéo dài, khó khăn khi thực hiện đường khâu cầm máu trong trường hợp chảy máu, hẹp miêng nối ....nên không được áp dụng trên lâm sàng.

Trên thực nghiệm, một số kỹ thuật ghép khác được nghiên cứu để làm giảm số miệng nối:

1957 Berman và cs, đã hợp nhất 2 tĩnh mạch phổi mỗi bên thành một mỏm để nối vào nhĩ trái người cho để giảm số miệng nối còn 6 . Sau đó đã nghiên cứu để lại mặt sau nhĩ trái người nhận, giảm còn 5 miệng nối.

- Cass và Brock (1959), Lower và Shumway (1960) [7] đưa ra khái niệm miêng nối 2 nhĩ và 2 động mạch, làm giảm còn 4 miệng nối.

Kỹ thuật 4 miệng nối này sau đó trở thành phương pháp chuẩn từ năm 1967 khi Barnard thực hiện trường hợp ghép tim trên người đầu tiên. Phần lớn nhĩ phải tim nhận được để lại, nhĩ trái tim cho được cắt một phần, nhĩ phải tim cho được rạch từ tĩnh mạch chủ dưới đến tiểu nhĩ phải. Ngay sau phẫu thuật nhĩ sẽ dãn nhanh tạo nên hình số 8 .

Về lý thuyết, sự thay đổi về hình thái học có thể ảnh hưởng đến huyết động, điện sinh lý, dẫn truyền thần kinh và chức năng van của tim ghép. Do đó, những kỹ thuật được thực nghiệm trước đây đã được giới thiệu áp dụng trên lâm sàng

- Năm 1989 Banner và cs lần đầu tiên áp dụng kỹ thuật ghép tim toàn phần gồm 6 miệng nối: 2 miệng nối ĐM, 2 miệng nối tĩnh mạch chủ ( bảo tồn nguyên vẹn của tâm nhĩ phải người cho) và 2 miệng nối tĩnh mạch phổi (bảo tồn sự nguyên vẹn của tâm nhĩ trái người cho).

- Năm 1991 Sievers và cs [8], [9] đã thực hiện kỹ thuật chủ-chủ , bảo tồn nhĩ phải nguyên vẹn. Thực hiện 2 miệng nối tĩnh mạch chủ, 2 miệng nối động mạch, và 1 miệng nối nhĩ trái (tương tự như kỹ thuật chuẩn) .

Trong 20 năm qua: kỹ thuật chủ- chủ đã trở thành phương pháp được sử dụng thường quy ở một số trung tâm ghép tạng

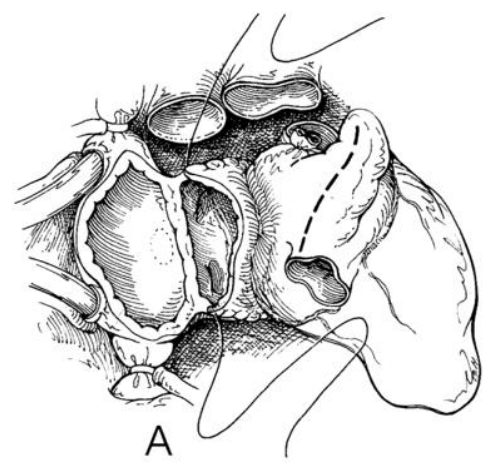

Kỹ thuật hai nhĩ

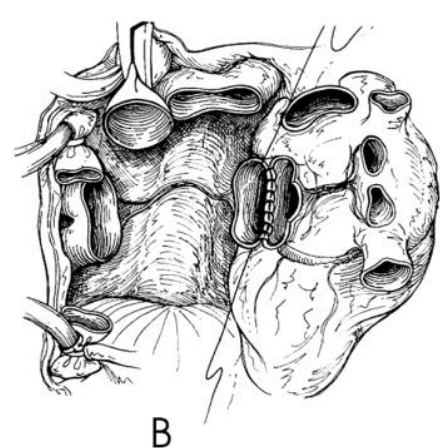

B

Kỹ thuật ghép toàn phần hai nhĩ

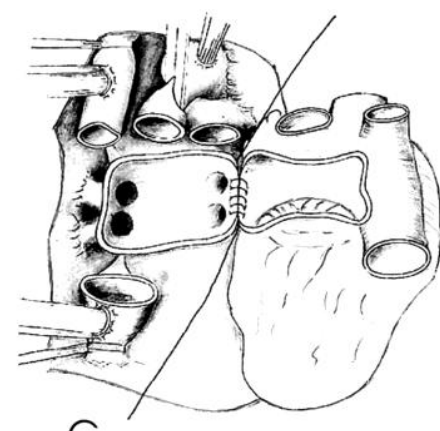

C

Kỹ thuật hai TM chủ

Hình 5: Ghép tim đồng vị trí theo các kỹ thuật khác nhau 
Tính ưu việt rõ rệt của kỹ thuật chủ-chủ trong ghép tim đồng vị trí khi so với kỹ thuật tiêu chuẩn qua các nghiên cứu tiến cứu:

- Tî̉ lệ nhịp xoang cao sau ghép tim

- Tỉ lệ hở van ba lá giảm rõ rệt

- Đề phòng được các bất thường co bóp do giãn nhĩ cấp khi dùng kỹ thuật tiêu chuẩn

- Sự mất đồng bộ (asynchrony) về phân bố thần kinh ở nhĩ giữa tim cho và tim nhận có lẽ đã góp phần vào những tác dụng huyết động có lợi trong kỹ thuật chủ-chủ.

- Đề phòng huyết khối do dãn nhĩ cấp (sau ghép bằng kỹ thuật tiêu chuẩn)

- Giảm nhu cầu phải tạo nhịp thường xuyên

Nghiên cứu Bernardi [3] cho thấy kỹ thuật chủ-chủ làm tăng tái phận bố thần kinh phó giao cảm nhiều hơn kỹ thuật tiêu chuẩn. Lợi ích lâm sàng: tăng kiểm soát áp lực máu bởi những thay đổi phản xạ trong nhịp tim , cải thiện sự thích nghi đối với những kích thích khác nhau và đối với gắng sức.

Hạn chế của kỹ thuật ghép tim chủ-chủ là thời gian liệt tim kéo dài hơn, khả năng hẹp tại các miệng nối tĩnh mạch chủ. Tuy vậy có thể khắc phục được bằng cách thực hiện miệng nối mà không kẹp động mạch chủ, và khâu tĩnh mạch chủ bằng mũi rời hoặc mũi khâu vắt nhưng xẻ rộng thêm miệng nối tĩnh mạch chủ. Ngoài ra, kỹ thuật ghép tim nhĩ-nhĩ cho kết quả tốt khi ghép tim đồng vị trí ở trẻ em và đặc biệt được lựa chọn khi kích thước các tĩnh mạch chủ người cho và nhận không tương xứng, hoặc trong những trường hợp mổ lại hoặc giải phẫu phức tạp.

Chúng tôi đã chuẩn bị khá kỹ để triển khai ghép tim tại Bệnh viện Trung ương Huế theo kỹ thuật hai tĩnh mạch chủ. Các kêt quả thu được tương đương với một số nghiên cứu tại các trung tâm ghép tim lớn trên thế giới, thậm chí các kết quả về thời gian thiếu máu tạng, thời gian cặp động mạch chủ (bảng 8)... ngắn hơn trong bối cảnh người nhận bệnh cơ tim dãn và chưa có tiền sử phẫu thuật lần nào. Điều quan trọng là những kết quả có ý nghĩa cải thiện chất lượng cuộc sống của người bệnh. Bệnh nhân hoàn toàn không có rối loạn nhịp sau mổ (hình 3 , bảng 9), huyết động ổn định ngay từ giai đoạn sớm sau ghép tim. Hình thái và chức năng tim ghép sau mổ hoàn toàn bình thường đảm bảo phân suất tống máu tốt. Đặc biệt trên bệnh nhân này trước mổ có tăng áp phổi trong bối cảnh suy tim giai đoạn cuối tiến triển xấu (bảng 4 và 5) nhưng vẫn còn trong giới hạn ghép tim (sức cản mạch máu phổi 3 đơn vị wood). Sự hồi phục áp lực động mạch phổi rất tốt và nhanh chóng (hình 3 , bảng 9 và 10 ) ,liệu pháp milrinone được ngừng sử dụng 48 giờ sau ghép.

Tình huống khá đặc biệt xảy ra khi trung hoà Heparin bằng liều thấp Protamin thì áp lực động mach hệ thống giảm và áp lực động mạch phổi tăng, chúng tôi quyết định không dùng Protamin và theo dõi nhưng không thấy chảy máu. Sau mổ, các biến chứng như chảy máu, nhiễm trùng, thải ghép cấp, và biến chứng do liệu pháp ức chế miễn dịch sau ghép (bảng 11) hầu như không xảy ra trên bệnh nhân này. Tuy vậy, những kết quả mà chúng tôi thu được sau hơn 1 năm ghép tim vẫn chưa thể kết luận hoàn toàn; nhưng nó góp phần chứng tỏ tính ưu việt của kỹ thuật ghép tim đồng vị trí kiểu hai tĩnh mạch chủ theo xu hướng ghép tim trên thế giới. Cùng với thời gian, chúng tôi sẽ có nhiều cơ hội hơn nữa để thực hiện kỹ thuật này, cũng như để đánh giá hiệu quả trên những bệnh nhân sau ghép tim trong những năm sắp đến.

\section{KẾT LUẬN}

Chúng tôi thực hiện thành công ca ghép tim đồng vị trí theo kỹ thuật hai tĩnh mạch chủ phù hợp với xu hướng hiện đại vì đây là một kỹ thuật có nhiều ưu điểm mặc dù có một vài khó khăn về kỹ thuật. Tuy nhiên, những tác dụng có lợi dài hạn của kỹ thuật chủ-chủ vẫn còn cần phải được đánh giá, đặc biệt là đối với khả năng gắng sức và chất lượng cuộc sống liên quan đến sức khỏe .

\section{TÀI LIỆU THAM KHẢO}

1. Aleksic I, Freimark D, Blanche C, Czer LS, Takkenberg JJ, Dalichau H, et al. Resting hemodynamics after total versus standard orthotopic heart transplantation in patients with high preoperative pulmonary vascular resistance. Eur J Cardiothorac Surg. 1997; 11 (6): 1037-44.

2. Aziz TM, Burgess MI, Rahman AN, Campbell CS, Deiraniya AK, Yonan NA. Risk factors for tricuspid valve regurgitation after orthotopic heart transplantation. Ann Thorac Surg. 1999; 68 (4): 1247-51.

3. Bernardi L. Influence of type of surgery on the occurrence of parasympathetic reinnervation after 
cardiac transplantation. Circulation 1998;97:13681374.

4. Blanche C, Nessim S, Quartel A, Takkenberg JJ, Aleksic I, Cohen M, et al. Heart transplantation with bicaval and pulmonary venous anastomoses: a hemodynamic analysis of the first 117 patients. J Cardiovasc Surg (Torino). 1997; 38 (6): 561-6.

5. Bộ Y tế, "Tiêu chuẩn lâm sàng, cận lâm sàng và các trường hợp không áp dụng tiêu chuẩn lâm sàng để xác định chết não", Quyết định số 32/2007/QĐBYT.

6. Jonathan B. Orens, MD., International Guidelines for the Selection of Heart and Lung Transplant candidates 2011. A Consensus Report From the
Pulmonary Scientific Council of the International Society for Heart and Lung Transplantation

7. Lower RR, Stofer RC, Shumway NE. Homovital transplantation of the heart. J Thorac Cardiovasc Surg. 1961; 41: 196-204.

8. Sievers HH, Leyh R, Jahnke A. Bicaval versus atrial anastomosis in cardiac transplantation. $\mathrm{J}$ Thorac Cardiovasc Surg. 1994; 108 (4): 780-4.

Schnoor M, Schäfer T, Lühmann D, Sievers HH. Bicaval versus standard technique in orthotopic heart transplantation: a systematic review and metaanalysis. J Thorac Cardiovasc Surg. 2007; 134 (5): 1322-31. 